\title{
PENGARUH PEMBERIAN AIR KELAPA TERHADAP KEBUGARAN ATLET SEPAK BOLA
}

\author{
Lana Alfiyana, Etisa Adi Murbawani* ${ }^{*}$ \\ Program Studi Ilmu Gizi Fakultas Kedokteran Universitas Diponegoro \\ Jl.Dr.Sutomo No.14, Semarang, Telp (024) 8453708, Email : gizifk@undip.ac.id
}

\begin{abstract}
Background: The athlete's fitness is one of the supporting factor for athlete's performance. Consumption of carbohydrate-electrolyte beverage during training maintain hydration status and athlete's performance. Coconut water is potential natural fluid that can be used as natural sport drink.

Objective: The aim of this study was to verify the effect of additional sugar in coconut water on soccer athlete's fitness

Methode: An experimental study was done in randomized pretest - post test design with a control group. The subject were 18 soccer's player aged 14-18 years at Persatuan Sepak Bola Kudus in August 2012. The control group is consumed pure coconut water and the treatment group is consumed coconut water which added with $3 \mathrm{~g}$ of sugar every $100 \mathrm{ml}$. The amount of fluid given based on fluid requirement during training. After physical training during 90minutes, all player completed the fitness test with cooper test 12 minutes run.

Result: Consumption of coconut water affect the results of $\mathrm{VO}_{2}$ max on control group (p=0.016), and has no significant effect on treatment group $(p=0,871)$. There no significant different between two groups in consumption of energy $(p=0.643)$, fluid before training $(p=0.385)$, body fat $(p=0,698)$ and muscle mass $(p=0.919)$

Conclusion: Consumption of pure coconut water affected on change value of $\mathrm{VO}_{2}$ max compared with coconut water which added with sugar.
\end{abstract}

Keywords : cocounut water; athlete's fitness; cooper test; $\mathrm{VO}_{2}$ max

\begin{abstract}
ABSTRAK
Latar Belakang: Kebugaran atlet merupakan salah satu faktor pendukung peforma atlet dilapangan. Konsumsi cairan berkarbohidrat elektrolit selama latihan dapat membantu menjaga status hidrasi, menunda kelelahan, dan menjaga performa. Air kelapa merupakan salah satu cairan yang berpotensi sebagai sport drink alami.

Tujuan: Penelitian ini bertujuan untuk mengetahui pengaruh penambahan karbohidrat pada air kelapa terhadap kebugaran atlet sepak bola

Metode: Studi Eksperimental dengan pendekatan randomized pretest-post test design dengan satu kelompok kontrol pada 18 atlet sepak bola usia 14-18 tahun di Persatuan Sepak Bola Kudus pada bulan Agustus 2012. Kelompok kontrol mengkonsumsi air kelapa murni, sedangkan kelompok perlakuan mengkonsumsi air kelapa dengan penambahan $3 \mathrm{~g}$ gula tiap $100 \mathrm{ml}$. Air kelapa yang diberikan sesuai dengan kebutuhan cairan atlet selama latihan. Setelah latihan selama 90 menit,atlet melaksanakan tes kebugaran menggunakan cooper test selama 12 menit.

Hasil: Penambahan gula pada air kelapa muda tidak mempengaruhi peningkatan $\mathrm{VO}_{2}$ maks pada kelompok perlakuan atlet sepak bola $(p=0,871)$, sedangkan peningkatan terjadi pada kelompok kontrol $(p=0,016)$. Tidak ada perbedaan asupan energi, asupan cairan sebelum latihan, persen lemak tubuh, dan persen massa otot pada kedua kelompok.

Kesimpulan: konsumsi air kelapa murni memberikan perubahan nilai $\mathrm{VO}_{2}$ maks pada kelompok kontrol, sedangkan penambahan gula pada air kelapa tidak memberikan perubahan nilai VO2 maks pada kelompok perlakuan.
\end{abstract}

Kata Kunci: Air Kelapa; kebugaran atlet,cooper test; $\mathrm{VO}_{2}$ Maks

\section{PENDAHULUAN}

Sepak bola adalah salah satu olahraga berintensitas tinggi yang membutuhkan kekuatan dan ketahanan tubuh selama pertandingan. Selama pertandingan pemain sepak bola dapat berlari menempuh jarak 10-12 km, melakukan aktifitas pendek yang berubah setiap 4-6 detik, sprint, berlari dalam intensitas tinggi, dan pergerakan pemain bersama bola. ${ }^{1}$. Performa atlet dilapangan ini berkaitan dengan keterampilan dan kebugaran yang didapat dari latihan rutin dan faktor psikologis atlet, didukung oleh asupan energi dan status hidrasi selama pertandingan. ${ }^{2}$

Menjaga keseimbangan cairan merupakan hal yang harus diperhatikan atlet selama latihan atau bertanding. Kegagalan dalam mempertahankan keseimbangan cairan dapat mempengaruhi peforma atlet. Kehilangan cairan 
sebanyak 3-5\% dari berat badan mengakibatkan gangguan fungsi kardiovaskular yang secara langsung berdampak pada peforma olahraga. ${ }^{3}$ Kehilangan cairan atau dehidrasi ini juga mengganggu pengaturan suhu tubuh, gangguan kognitif, dan mempercepat kelelahan. Kelelahan ini juga terjadi karena penurunan simpanan glikogen hati, glikogen otot,dan glukosa darah. ${ }^{3-5}$

Pemberian minuman yang mengandung karbohidrat dapat membantu tubuh untuk mencegah dehidrasi, menjaga konsentrasi glukosa darah dan simpanan glikogen. ${ }^{4,5}$ Pemberian sport drink dengan kandungan karbohidrat 6-8\% dapat membantu meningkatkan performa atlet. ${ }^{3}$ Air kelapa merupakan cairan alami yang kandungan karbohidrat dan elektrolitnya mirip sport drink. Bedasarkan pemeriksaan kandungan zat gizi di Laboratorium Pangan UNIKA, air kelapa muda mengandung karbohidrat 3,6\% dengan kandungan elektrolit yang paling banyak adalah kalium sebesar $220 \mathrm{mg}$, sedangkan kandungan natrium sebanyak $105 \mathrm{mg}{ }^{6}$. Namun jumlah kandungan karbohidrat pada air kelapa ini masih kurang apabila dibandingakan dengan jumlah karbohidrat pada sport drink yaitu 6-8\%, sedangkan kandungan natrium dalam sport drink 110-165 mg dengan sedikit kalium.

Masa remaja merupakan masa percepatan pertumbuhan dan perkembangan. Percepatan pertumbuhannya lebih cepat daripada masa anakanak. Pada atlet remaja pertumbuhan dan perkembangan yang terjadi pada fase ini adalah pertambahan tinggi badan, berat badan, konsumsi oksigen maksimal ( $\mathrm{VO}_{2}$ maks), kapasitas aerobik, dan kekuatan otot. ${ }^{7}$ Atlet remaja pun memiliki resiko dehidrasi lebih tinggi daripada atlet dewasa. Pada atlet remaja kehilangan cairan terjadi karena produksi panas tubuh saat berolahraga lebih tinggi dibandingkan atlet dewasa sehingga simpanan cairan yang ada didalam tubuh digunakan untuk menurunkan panas tubuh. Atlet remaja juga lebih sedikit berkeringat. Hal ini terjadi karena kemampuan tubuh yang rendah untuk mentransfer panas hasil kontraksi otot ke lapisan kulit sehingga menyebabkan penurunan penyaluran panas tubuh melalui pengeluaran keringat. Apabila asupan cairan kurang saat pertandingan dapat meningkatkan tingkat dehidrasi pada atlet usia remaja. $^{7}$

Penelitian tentang pengaruh pemberian air kelapa sebagai sport drink terhadap kebugaran atlet belum banyak ditemukan. Penelitian ini bertujuan untuk mengetahui pengaruh pemberian tambahan gula pada air kelapa muda terhadap kebugaran jasmani sebagai penunjang performa pada atlet sepak. Penelitian ini dilaksanakan di PERSIKU U18 karena klub ini beranggotakan atlet remaja dari tim yang sedang berkembang dan selalu ingin meningkatkan performa para atletnya agar berprestasi dalam setiap kompetisi yang diikuti. Pada tahun 2011 Persiku U18 berhasil mendapat juara 1 dalam Piala Suratin se Jawa Tengah, tahun 2012 juara 1 turnamen segi empat di Karang Malang, dan juara 2 turnamen segi empat di Semarang. Selain itu PERSIKU U-18 merupakan klub yang dapat dijangkau oleh peneliti dan klub tersebut menggunakan air putih sebagai cairan rehidrasi selama latihan.

\section{METODE PENELITIAN}

Penelitian ini dilakukan di PERSIKU U18 pada bulan Agustus 2012. Penelitian ini merupakan penelitian eksperimental dengan pendekatan randomized pretest - post test design with a control group dan termasuk dalam ruang lingkup gizi olah raga. Subjek penelitian adalah atlet sepak bola yang dipilih dengan secara purposif sedangkan alokasi pembagian kelompok secara random yaitu semua subjek yang memenuhi kriteria inklusi memiliki kesempatan yang sama untuk masuk dalam kelompok kontrol maupun kelompok perlakuan. ${ }^{8}$ Kriteria inklusinya antara lain berusia 14-18 tahun yang berada di PERSIKU U18, tidak sedang cedera atau dalam perawatan dokter, tidak mengonsumsi sport drink selain yang diberikan, tidak mengonsumsi suplemen sumber vitamin dan mineral atau suplemen yang berfungsi sebagai pembangkit tenaga selama penelitian berlangsung, serta bersedia mengikuti penelitian melalui persetujuan Informed Consent. Jumlah sampel minimal yang diperlukan adalah 10 orang tiap kelompok

Variabel bebas pada penelitian ini adalah air kelapa muda yang merupakan jenis dari buah kelapa dalam varietas Viridis, atau lebih dikenal dengan kelapa hijau. Buah kelapa ini dipasok dari satu tempat yaitu perkebunan kelapa Jepara. Air kelapa ini baru dibuka dari buahnya 3-5 jam sebelum diberikan kepada subjek, yang sebelumnya sudah didinginkan dalam kotak es. Kemudian air kelapa ini diporsikan ke dalam botol diberikan setiap 15-20 menit sesuai kebutuhan masing-masing atlet selama 5 hari saat latihan maupun saat test kebugaran akhir. Kelompok kontrol mendapatkan air kelapa murni, sedangkan kelompok perlakuan mendapatkan air kelapa ditambah 3 g gula tiap $100 \mathrm{ml}$. 
Variabel terikat pada penelitian ini adalah kebugaran atlet yang diukur menggunakan metode Cooper Test yakni lari selama 12 menit pada lintasan lari 400 meter untuk mengetahui kebugaran melalui nilai $\mathrm{VO}_{2}$ maksimal yang diperoleh. Tes kebugaran ini dilaksanakan setelah 90 menit latihan fisik dan dilakukan sebelum dan sesudah diberikan perlakuan. Variabel kontrol pada penelitian ini adalah asupan energi, asupan cairan, dan komposisi tubuh, untuk memperkecil bias variabel yang ikut mempengaruhi kebugaran jasmani atlet.

Rangkaian penelitian ini dilakukan selama 7 hari, Hari pertama dan kedua merupakan pengambilan data awal antropometri, recall asupan dan $\mathrm{VO}_{2}$ maks awal. Hari ketiga sampai ketujuh, selama 5 hari kedua kelompok perlakuan diberikan latihan fisik yang sama selama penelitian, hanya berbeda pada pemberian air minum selama latihan. Selama 90 menit latihan, setiap 15-20 menit kelompok kontrol rata-rata mendapatkan air kelapa murni $1,4 \pm 0,16$ liter dan kelompok perlakuan rata-rata mendapatkan air kelapa yang sudah diberi tambahan gula $1,5 \pm 0,17$ liter. Pemberian air kelapa ini bertujuan untuk membiasakan kedua kelompok meminum air kelapa yang digunakan untuk pengambilan data $\mathrm{VO}_{2}$ maks akhir di hari ketujuh.

Data yang dikumpulkan meliputi data berat badan, tinggi badan, persen lemak tubuh, persen massa otot, asupan energi, asupan cairan sebelum latihan dan pengukuran kebugaran. Pengukuran berat badan diperoleh melalui penimbangan menggunakan timbangan injak digital dengan ketelitian $0,1 \mathrm{~kg}$. Pengukuran tinggi badan diperoleh melalui pengukuran menggunakan microtoise dengan batas ukur $200 \mathrm{~cm}$ dan ketelitian $0,1 \mathrm{~cm}$. Persen lemak tubuh dan persen massa otot didapatkan melalui pengukuran menggunakan Bioelectric Impedance Analyzer (BIA) injak dengan merk LAICA, seri: Art PL 8032 . Asupan energi selama penelitan didapat melalui formulir recall 24 jam. Waktu yang diperlukan untuk menyelesaikan tes lari yang telah ditentukan diukur menggunakan stopwatch dengan ketelitian 0,01 detik. Analisis data dilakukan dengan menggunakan program komputer. Analisis univariate untuk mendeskripsikan karakteristik subjek penelitian yaitu berat badan, tinggi badan, persen lemak tubuh, persen massa otot, asupan energi, asupan cairan sebelum latihan dan $\mathrm{VO}_{2}$ maks awal dan akhir. Analisis bivariate diawali dengan uji kenormalan data yaitu uji Sapiro-Wilk, kemudian dilanjutkan dengan uji beda Independent t-test dan paired t-test untuk data berdistribusi normal, dan uji Wilcoxon untuk data berdistribusi tidak normal. Data asupan energi dan asupan cairan diperoleh dari hasil food recall dianalisis dengan bantuan program nutrisurvey.

\section{HASIL PENELITIAN}

Penelitian dilakukan di PERSIKU U18 pada bulan Agustus 2012. Subjek penelitian merupakan atlet sepak bola berusia 14-18 tahun. Sebanyak 24 orang bersedia menjadi subjek, dan semuanya memenuhi kriteria inklusi, kemudian dari 24 orang tersebut diacak dan dibagi kedalam dua kelompok. Selama penelitian dua orang dari kelompok kontrol dan empat orang dari kelompok perlakuan drop out karena tidak mengikuti tes yang dilakukan pada akhir penelitian. Jumlah subjek yang mengikuti penelitian sampai akhir berjumlah 18 orang.

\section{Karakteristik Subjek Penelitian}

Karekteristik subjek penelitian dari kelompok kontrol dan kelompok perlakuan disajikan dalam Tabel 1.

Tabel 1 Karateristik Subjek Penelitian

\begin{tabular}{|c|c|c|c|}
\hline \multirow[t]{2}{*}{ Karakteristik subjek } & Kontrol(n=10) & Perlakuan $(\mathrm{n}=8)$ & \multirow[b]{2}{*}{$p$} \\
\hline & Rerata \pm SD & Rerata \pm SD & \\
\hline Usia (tahun) & $14,5(14-18)$ & $14,5(14-17)$ & $0,962 * *$ \\
\hline Berat Badan $(\mathrm{kg})$ & $55,23+5,98$ & $52,76 \pm 7,95$ & $0,463 *$ \\
\hline Tinggi Badan $(\mathrm{cm})$ & $161(159-173)$ & $162,5(159-174)$ & $0,394 * *$ \\
\hline $\operatorname{IMT}\left(\mathrm{kg} / \mathrm{m}^{2}\right)$ & $20,75 \pm 1,66$ & $19,51 \pm 2,74$ & $0,252 *$ \\
\hline Persen massa otot (\%) & $50,89 \pm 2,36$ & $50,78 \pm 2,32$ & $0,919 *$ \\
\hline Persen lemak tubuh (\%) & $6,85(5,1-15,1)$ & $7,2(5,1-14,4)$ & $0,689 * *$ \\
\hline Asupan energi (kkal) & $2024,57 \pm 273,54$ & $2092,69 \pm 339,34$ & $0,643 *$ \\
\hline $\begin{array}{l}\text { Asupan cairan sebelum latihan } \\
\text { (liter) }\end{array}$ & $1,97 \pm 0,65$ & $2,22 \pm 0,49$ & $0,385^{*}$ \\
\hline Asupan air kelapa selama latihan & $1,4 \pm 0,16$ & $1,56 \pm 0,17$ & $0,051^{*}$ \\
\hline
\end{tabular}




\section{(liter) \\ *Independent T test \\ *Uji Mann-Whitney}

Keseluruhan data pada karakteristik subjek penelitian menunjukkan bahwa kedua kelompok tidak ada perbedaan bermakna dari variabel usia,berat badan, tinggi badan, dan indeks massa tubuh $(\mathrm{p}>0,05)$. Variabel yang di kontrol dalam penelitian ini seperti asupan energi, asupan cairan sebelum latihan, dan komposisi tubuh juga menunjukkan tidak ada perbedaan bermakna pada kedua perlakuan $(p>0,05)$. Kedua kelompok pada penelitian ini memiliki karakteristik yang sama.

\section{Karakteristik Kebugaran Subjek Penelitian}

Kebugaran subjek sebelum dan sesudah diberikan air kelapa disajikan dalam Tabel 2.

Tabel 2. Hasil Tes Kebugaran Subjek Penelitian

\begin{tabular}{llll}
\hline \multirow{2}{*}{ Tes Kebugaran } & Kontrol (\%) & Perlakuan $(\%)$ & \multirow{2}{*}{$p$} \\
\cline { 2 - 3 } & Rerata $\pm \mathrm{SD}$ & Rerata $\pm \mathrm{SD}$ & \\
\hline $\mathrm{VO}_{2}$ Maks pre $(\mathrm{ml} / \mathrm{kg} /$ menit $)$ & $50.25 \pm 7.85$ & $49.95 \pm 10$ & 0.945 \\
$\mathrm{VO}_{2}$ Maks post $(\mathrm{ml} / \mathrm{kg} /$ menit $)$ & $57.41+11.41$ & $50.56+2.87$ & 0.96 \\
\hline
\end{tabular}

Hasil tes kebugaran menunjukkan tidak ada perbedaan bermakna pada nilai $\mathrm{VO}_{2}$ maks pre test $(\mathrm{p}=0,945)$ dan post tes $(\mathrm{p}=0,96)$ pada kedua kelompok. Kebugaran subjek kedua kelompok diawal dan diakhir penelitian berada dalam kondisi yang sama.

\section{Perbedaan Kebugaran Kelompok Kontrol dengan Kelompok Perlakuan}

Perbedaan nilai $\mathrm{VO}_{2}$ Maks masing-masing kelompok setelah diberikan air kelapa disajikan dalam Tabel 3.

Tabel 3. Perbedaan Kebugaran Kelompok Kontrol Dengan Kelompok Perlakuan

\begin{tabular}{lllll}
\hline \multirow{2}{*}{ Jenis Perlakuan } & Pre test & Post test & \multirow{2}{*}{$\Delta$} & \multirow{2}{*}{$p$} \\
\cline { 2 - 4 } & Rerata + SD & Rerata + SD & & \\
\hline Kontrol & $50,25+7,85$ & $57,41+11,41$ & 7,16 & $0,016^{*}$ \\
Perlakuan & $49,95+10$ & $50,56+2,87$ & 0,61 & 0,871 \\
\hline * paired t test $\mathrm{p}<0.05$ & & & &
\end{tabular}

Terdapat peningkatan nilai $\mathrm{VO}_{2}$ maks pada kelompok kontrol setelah diberikan air kelapa murni dengan perbedaan rerata bermakna $(\mathrm{p}=0,016)$. Pada kelompok perlakuan tidak ada peningkatan setelah diberikan air kelapa yang diberi tambahan gula $(\mathrm{p}=0,871)$. Peningkatan nilai $\mathrm{VO}_{2}$ maks pada kelompok kontrol juga dapat dilihat dari selisih nilai sebelum dengan setelah diberikan air kelapa yang cukup besar.

\section{PEMBAHASAN}

Penelitian ini menggunakan subjek sebanyak 18 orang yang terbagi dalam dua kelompok. Kelompok kontrol berjumlah 10 subjek, sedangkan kelompok perlakuan berjumlah 8 subjek. Pada penelitian ini selama 5 hari kelompok kontrol mendapat air kelapa muda murni dan kelompok perlakuan mendapat air kelapa muda dengan tambahan gula. Hasil nilai $\mathrm{VO}_{2}$ maks menunjukkan terdapat perbedaan bermakna sebelum dan setelah pemberian air kelapa pada kelompok kontrol $(\mathrm{p}=0,016)$, sedangkan tidak ada perbedaan bermakna pada kelompok perlakuan ( $\mathrm{p}=0,871)$. Hasil analisis statistik juga menunjukkan asupan energi $(\mathrm{p}=0,643)$, asupan cairan sebelum latihan $(\mathrm{p}=0,385)$, persen lemak tubuh $(p=0,689)$, dan persen massa otot $(p=0,919)$ tidak berbeda pada kedua kelompok. Tidak adanya perbedaan pada variabel tersebut menunjukkan bahwa kedua kelompok dalam kondisi yang sama saat penelitian ini dilakukan. Kebugaran merupakan salah satu penentu peforma atlet. $\mathrm{VO}_{2}$ maks merupakan prediktor yang dapat menggambarkan kebugaran seorang atlet dilihat dari kemampuan daya jantung paru. Asupan energi, asupan cairan, dan komposisi tubuh merupakan faktor pendukung kebugaran atlet. Namun, selain dari variabel tersebut, kebugaran seorang atlet juga ditentukan oleh berbagai faktor diantaranya, latihan, aktifitas harian, waktu 
istirahat dan pemulihan, serta faktor psikologis saat test dilaksanakan. ${ }^{2}$

Salah satu cara untuk mempertahankan kebugaran atlet adalah dengan menjaga agar tubuh tetap terhidrasi dengan baik melalui pengaturan asupan cairan. Status hidrasi dapat mempengaruhi kebugaran seorang atlet. Hasil penelitian dari Teresa et al menunjukkan bahwa kebugaran sampel yang dilihat dari $\mathrm{VO}_{2}$ maks saat mengalami dehidrasi $(3398,3 \pm 795,5 \mathrm{ml} / \mathrm{min})$ lebih rendah daripada saat sampel dalam kondisi terhidrasi dengan baik $(3763,8 \pm 840,3 \mathrm{ml} / \mathrm{min}){ }^{9}$ Penggunaan minuman berkarbohidrat elektrolit atau sport drink dapat menjadi solusi untuk mencegah dehidrasi sekaligus sumber energi yang mudah dikonsumsi selama latihan. Konsumsi cairan yang mengandung karbohidrat selama pertandingan berlangsung dapat membantu menjaga konsentrasi glukosa darah dan mempertahankan ketersediaan glikogen otot, serta membantu meningkatkan performa. ${ }^{5}$ Hasil penelitian dari Ajmol et al menunjukkan subjek yang diberi minuman sport drink dengan kandungan karbohidrat 5\% dapat melakukan sprint lebih cepat dari kelompok yang tidak diberi minuman sport drink.${ }^{10}$ Sedangkan hasil penelitian oleh Sergej et al menunjukkan pemberian sport drink dengan kandungan karbohidrat 7\% meningkatkan catatan waktu dribble dan membantu memperbaiki performa keterampilan atlet. $^{11} \quad$ Pada tahun 2000 Food and Agricultural Organization (FAO) menyebutkan bahwa air kelapa muda berpotensi sebagai sport drink alami. ${ }^{13}$ Hasil penelitian yang membandingkan efek rehidrasi menggunakan sport drink dengan air kelapa menunjukkan bahwa air kelapa memiliki efek rehidrasi yang mirip dengan sport drink. ${ }^{14,15}$ Sehingga air kelapa juga dapat digunakan untuk rehidrasi pada atlet yang sedang latihan atau bertanding. Karakteristik dari sport drink adalah kandungan karbohidrat $14 \mathrm{~g}$ dalam 237 ml cairan atau sekitar $5-7 \%$ dan natrium sebesar 110-165 mg. ${ }^{5}$ Kandungan karbohidrat yang baik untuk dikonsumsi oleh atlet selama latihan adalah $6-8 \%{ }^{3,12}$

Air kelapa mengandung karbohidrat sebanyak 3,6\%. Kandungan karbohidrat tersebut masih kurang bila dibandingkan dengan kandungan karbohidrat sport drink yang optimal untuk dikonsumsi. Penambahan karbohidrat $3 \mathrm{~g}$ gula tiap $100 \mathrm{ml}$ air kelapa pada kelompok perlakuan bertujuan untuk meningkatkan kandungan karbohidrat dalam air kelapa. Karbohidrat yang menjadi sumber energi utama bagi atlet dalam sistem aerobik dan satu-satunya zat gizi makro yang dapat dimetabolisme untuk energi secara anaerobik. Karbohidrat memproduksi energi lebih efisien dari lemak dan protein. Karbohidrat yang masuk kedalam tubuh, setelah dimetabolisme menjadi karbohidrat sederhana yaitu glukosa, fruktosa, dan galaktosa yang kemudian diabsorbsi dan ditransportasi untuk digunakan sebagai energi dan ada pula yang disimpan di dalam tubuh. Salah satu simpanan glukosa didalam tubuh adalah glikogen ${ }^{3}$.

Olahraga sepak bola merupakan kombinasi antara metabolisme aerobik dan anaerobik yang menyebabkan tubuh bergantung pada simpanan glikogen otot sebagai penyedia energi. Simpanan glikogen dalam otot menentukan performa dalam sepak bola karena besarnya simpanan glikogen dalam tubuh akan menentukan performa saat latihan maupun pertandingan. Olahraga yang membutuhkan daya tahan dan waktu lebih dari 90 menit menyebabkan simpanan glikogen otot dengan cepat akan berkurang. Konsumsi karbohidrat dalam jumlah yang tepat dapat membantu meningkatkan performa atlet. Meskipun demikian konsumsi karbohidrat berlebihan dapat menyebabkan gangguan saluran cerna. Cairan dengan kandungan karbohidrat $>8 \%$ perlu dihindari karena dapat memperlambat proses absorpsi cairan di dalam tubuh dan menimbulkan gangguan pencernaan, sehingga menghambat rehidrasi dan mengganggu peforma atlet. ${ }^{5,12}$ Konsumsi karbohidrat selama latihan sebaiknya disesuaikan dengan jenis latihannya. Konsumsi karbohidrat akan lebih optimal pada jenis latihan berintensitas tinggi selama lebih dari satu jam seperti juga pada latihan berintensitas lebih rendah tetapi dalam jangka waktu yang cukup panjang. ${ }^{18}$ Hasil dari penelitian ini kelompok perlakuan yang mendapatkan tambahan karbohidrat tidak menunjukkan peningkatan nilai $\mathrm{VO}_{2}$ maks.

Selama latihan tubuh akan mengeluarkan keringat, selain kehilangan cairan tubuh juga akan kehilangan elektrolit yang terkandung dalam keringat. Elektrolit yang hilang selama berkeringat ini adalah natrium dan kalium. Elektrolit yang hilang tergantung seberapa banyak total cairan yang hilang dan konsentrasi elektrolit tersebut dalam keringat. Rata-rata konsentrasi natrium dalam keringat adalah $35 \mathrm{mEq} / \mathrm{L}$, sedangkan konsentrasi kalium $5 \mathrm{mEq} / \mathrm{L}{ }^{18}$ Jumlah elektrolit yang hilang ini juga bervariasi tergantung dari asupan makan, volume keringat, dan aklimatisasi terhadap suhu panas. Cairan rehidrasi yang baik, selain mengandung karbohidrat juga harus 
mengandung elektrolit untuk menggantikan elektrolit yang hilang melalui keringat. Mineral elektrolit yang hilang melalui keringat mempunyai berbagai fungsi yang mendukung performa atlet, sehingga kehilangan elektrolit tersebut harus cepat diganti. Fungsi dari natrium dapat membantu absorbsi glukosa. Natrium juga berfungsi untuk kontraksi otot bersama kalium. Kedua mineral ini juga berperan penting dalam menjaga keseimbangan cairan tubuh dan fungsi kardiovaskuler. $^{3}$

Pemberian elektrolit harus disesuaikan dengan banyaknya elektrolit yang hilang melalui keringat. Direkomendasikan cairan rehidrasi mengandung natrium sebanyak $20-30 \mathrm{mEq} / \mathrm{L}$ dan 2-5 $\mathrm{mEq} / \mathrm{L} .^{18}$ Namun kebutuhan tersebut tergantung dari durasi dan intensitas latihan, serta kondisi lingkungan dan suhu. Pengeluaran keringat pada atlet sepak bola dapat bervariasi tiap pemain tergantung posisi, gaya permainan, dan banyaknya waktu yang digunakan dilapangan. ${ }^{18}$ Air kelapa juga mengandung elektrolit dengan kandungan terbanyak dalam air kelapa adalah kalium $220 \mathrm{mg}$ per $100 \mathrm{ml}$, sedangkan natrium $105 \mathrm{mg}^{6}$. Jumlah tersebut belum sebanding dengan konsentrasi elektrolit yang hilang melalui keringat. Konsentrasi natrium dalam keringat lebih tinggi daripada kalium sedangkan pada air kelapa konsentrasi kalium lebih tinggi daripada natrium.

Kebugaran atlet juga didukung oleh asupan energi dan komposisi tubuh. Asupan energi merupakan gambaran dari ketersediaan energi dalam tubuh yang didapat dari makanan. Bagi atlet remaja, energi ini juga dibutuhkan untuk pertumbuhan disamping menyediakan energi selama berlatih atau bertanding. ${ }^{7}$ Sumber energi utama bagi seorang atlet berasal dari karbohidrat. Keterbatasan asupan karbohidrat, mengakibatkan penggunaan simpanan lemak dan protein sebagai sumber energi, sehingga dapat mengakibatkan kehilangan massa otot, meningkatkan resiko kelelahan dan cidera. ${ }^{16}$ Komposisi tubuh dan berat badan adalah salah satu faktor yang memberi kontribusi terhadap kebugaran. ${ }^{16}$ Hasil penelitian Amani et al menunjukkan bahwa terdapat korelasi negatif antara nilai $\mathrm{VO}_{2}$ maks dengan lemak tubuh $^{17}$, artinya semakin tinggi lemak tubuh, semakin rendah nilai $\mathrm{VO}_{2}$ maks, dengan demikian kebugaran semakin menurun pula. Komposisi lemak tubuh dan massa otot ikut menentukan total cairan tubuh. Sekitar $70-80 \%$ dari massa otot mengandung cairan, sedangkan pada lemak hanya $10 \%{ }^{18}$ Otot mampu menyimpan cairan lebih banyak daripada lemak. Semakin besar persen lemak tubuh, maka simpanan cairan tubuh lebih sedikit, sehingga dehidrasi akan lebih cepat terjadi.

Keterbatasan dari penelitian ini adalah jumlah subjek penelitian yang terbatas dan banyak subjek yang drop out di tes kebugaran akhir karena adanya jadwal pertandingan, serta faktor aktifitas diluar olah raga dan jenis latihan yang tidak diukur .Selain itu, jarak waktu yang cukup jauh antara pengukuran kandungan air kelapa dengan penelitian, memungkinkan adanya perubahan jumlah karbohidrat pada air kelapa, sehingga penambahan gula yang tidak tepat pada air kelapa muda bisa mengganggu performa atlet. Waktu penelitian yang singkat dan jumlah subjek yang tidak memenuhi jumlah sampel minimal,ikut mempengaruhi hasil dari penelitian ini.

\section{SIMPULAN}

Pemberian air kelapa muda meningkatkan nilai $\mathrm{VO}_{2}$ maks atlet sepak bola. Pemberian air kelapa muda ini dapat digunakan sebagai cairan rehidrasi alternatif pengganti sport drink. Penambahan gula pada air kelapa tidak memberikan efek peningkatan nilai $\mathrm{VO}_{2}$ maks.

\section{SARAN}

1. Diperlukan penelitian lebih lanjut mengenai pengaruh air kelapa muda dengan jumlah subjek penelitian yang lebih banyak.

2. Diperlukan penelitian lebih lanjut untuk modifikasi komposisi air kelapa sehingga komposisi karbohidrat dan elektrolitnya optimal untuk digunakan sebagai sport drink

3. Untuk mengetahui efek rehidrasi pemberian air kelapa terhadap kebugaran, sebaiknya tes kebugaran dilakukan sebelum dan sesudah latihan.

\section{DAFTAR PUSTAKA}

1. Tomas S, Karim C, Calro C, Ulrik W. Physiology of soccer an update. Sports Med 2005; 35(6) : 501-36.

2. Abidin, Zainal. Pemahaman dasar sport science dan penerapan iptek olahraga. Bagian Sport Science dan Penerapan Iptek Olahraga Komite Olahraga Nasional Indonesia. [serial online] [dikutip 2012 Mar 15]. Tersedia URL: http://koni.or.id/sport-science/pemahaman-dasarsport-science-dan-iptek-olahraga/

3. Heater H F, Lisa A B, Alan E M. Practical application in sports nutririon. Massachusetts : Jones and Bartlett Publisher.2006. p82-83;199202;224-226;326;434;470-475.

4. Melvin H W. Nutrition for health, fitness, and sport. New York : McGraw-Hill.2007. p.130; 334. 
5. Dorfman L. Nutrition for exercise and sports performance. In: Mahan LK, Sylvia Escott-Stump. Krause's food, nutrition, \& diet therapy. 11th ed. Philadelphia: Saunders; 2008.p.590-602.

6. United States Department of Agriculture (USDA). National nutrient database for standard reference, 2008. Nuts, coconut water [serial Online][dikutip Juni 2012]. Tersedia URL: http://www.nal.usda.gov/fnic/foodcomp/cgibin/list nut edit.pl/

7. Stang J. Nutrition in adolescence. In : Mahan LK, Sylvia Escott-Stump. Krause's food, nutrition, \& diet therapy. 11th ed. Philadelphia: Saunders; 2008.p246-251

8. Sastroasmoro S, Ismael S. Dasar dasar metodologi penelitian klinis edisi ke-3. Jakarta; Sagung Seto; 2008. Hal.312,88

9. Teresa L S, Joseph W P. Effect of hydration state on heart rate-based estimates of $v_{2}$ max. Journal of Exercise Physiology 2004;7(1):19-6

10. Ajmol A, Clyde W, Ceri WN, Andrew F. The influence of carbohydrate electrolyte ingestion on soccer skill performance. The American College of Sports Medicine 2007;1969-8.

11. Sergej M, Ostojic, Sanja M. Effects of carbohydrate-electrolyte drink on spesific soccer tests and performance. Journal of Sport Science and Medicine 2002;47-6.

12. Casa DJ, Lawrence EA, Scott JM, Susan KH, Ralph VR, Brent S.E.F, et all. National athletic trainers' association position statement: fluid replacement for athletes. Journal of Athletic Training.[serial online] 2000 [dikutip 2012 sept 22]; 35(2): [12 halaman]. Tersedia URL: http:// www.ncbi.nlm.nih.gov/pmc/ articles/PMC1323420/pdf/jathtrain00002-0094.pdf

13. Food and Agriculture Organization . New sport drink: coconut water. [serial online] 2000 [dikutip 2012 Mar 1]. Tersedia URL : http://www.fao.org/ag/magazine/9810/spot3.htm

14. Mohamed S, Rabindarjeet S, Roland G S, Mohd N. Rehydration after exercise with fresh young coconut water, carbohydrate-electrolyte beverage and plain water. J Physiol Anthropol 2002; 21(2) : 93-12

15. Douglas S K, Samantha F, Diane RK, Richard J B. Comparison of coconut water and carbohydrateelectrolyte drink on measures of hydration and physical performance in exercice-trined men. Journal of the International Society of Sports Nutrition 2012; 9(1) : [30 halaman].

16. Position of the America Dietetic Association, Dietetians of Canada and the America College of Sport Medicine. Nutrition and athletic performance. Official Journal of American College of Sport Medicine 2009;709-23.

17. Amani AR, Somchit MN, Konting MM. Relationship between body fat percent and maximal oxygen uptake among young adults.
Journal of American Science. [serial online] 2010 [dikutip 2012 sept 17]; 6 (4); p.1-4. Tersedia URL: http://www.jofamericanscience.org/journals/amsci/ am0604/01_2002_physiology_am0604_1_4.pdf

18. Michael N S, Louise M B, Randy E, Ronald J M, Scott J M, Nina M S. Exercice and fluid replacement. American College of Sport Medicine 2007;377-14 